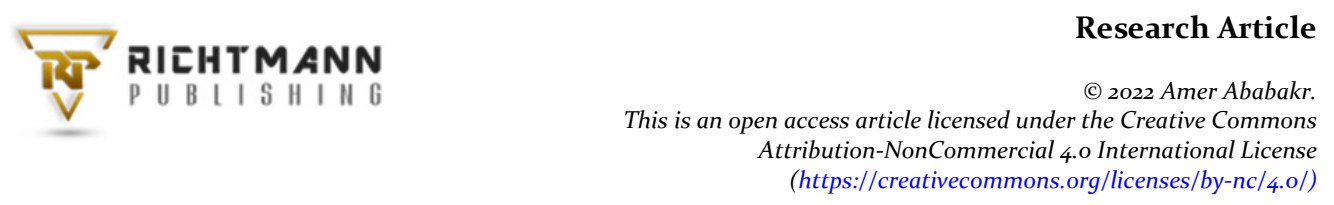

Received: 26 December 2021 / Accepted: 28 February 2022 / Published: 5 March 2022

\title{
Federalism As a Tool for Ethnic Conflict Resolution: A Case Study of Iraq
}

\author{
Amer Ababakr \\ PhD. Cyprus International University, \\ Haspolat, Northern Cyprus
}

DOI: https://doi.org/10.36941/mjss-2022-0o17

\begin{abstract}
Due to ethnic, linguistic and cultural diversities, there is potential for ethnic conflicts and ethnic tensions in community, but the emergence and occurrence of ethnic conflicts depend on the state's approach to managing or suppressing ethnic, linguistic, and cultural variations. Federalism is one of the most important mechanisms that governments adopt to manage ethnic, linguistic and cultural diversities. But the function of federalism in reducing ethnic conflicts is not necessarily positive, and in some cases, it has led to an escalation of ethnic conflicts. Accordingly, the central question is to examine whether federalism is a system to resolve or reduce ethnic conflicts? With an emphasis on ethnic conflicts in Iraq. The research hypothesis is that federalism, through the creation of bureaucratic structures, the development of political parties, the identification, and acceptance of cultural and linguistic commonalities, will restrict and reduce ethnic violence and conflict but not necessarily ethnic protest.
\end{abstract}

Keywords: ethnic conflict, ethnicity, federalism, Iraq, Arabs, Kurds

\section{Introduction}

The main aim of implementing the federal system is to provide the ideal platform for reducing conflicts and accepting the diversity of religious and multicultural groups. Federalism tends to decentralize power from the center. The lack of integration and the diverse and multifaceted fabric of societies have led federalism to be considered as a way for a good governance system for community and a peaceful way of life for people to live alongside each other. Meanwhile, the experience and influence of federalism in different societies are not the same. In some countries with diverse ethnic, race and religions such as the Switzerland, New Zealand, Denmark, Sweden, Finland, Luxembourg, Canada, Norway, United Kingdom and Australia federalism is a handy mechanism for managing ethnic diversity and relieving ethnic tensions. In some other societies like the UK and Spain, federalism has not been able to reduce the incentives of ethnic groups to achieve independence. These experiences are mostly in communities that have undergone the process of nation-building since many years ago, especially dating back to the mid-nineteenth century, but the experience of federalism in societies that are still at the start of the process of nation-building and on the other hand, they have a diverse religious and ethnic context is very different. However, these communities are also trying to use federalism as a mechanism for reducing ethnic tensions and armed conflicts among ethnic groups. Thus, the impact of federalism on ethnic conflicts can be an essential issue for research in these societies. 
Considering that Iraq is a multi-ethnic and multi-religious country, it has elected federalism as its future system of government in accordance with Article 4 of the Interim Constitution and Article 1 of the Permanent Constitution. The system of federalism in Iraq is the type of ethnic federalism (Horowitz, 1985), because, according to Section 1 of Article 114 in the Permanent Constitution, Iraqi federalism is ethnic federalism due to the recognition and establishment of the Kurdish-dominated region. Based on this the current paper examines the relationship between Kurds and Arabs as the two main ethnic groups in Iraq. Accordingly, the central question of the research is to investigate whether federalism is a system to resolve or reduce ethnic conflicts? With an emphasis on ethnic conflicts in Iraq. The research hypothesis is that federalism, through the creation of bureaucratic structures, the development of political parties, the identification, and acceptance of cultural and linguistic commonalities, will restrict and reduce ethnic violence and conflict but not necessarily ethnic protest. The research methodology is an explanatory explanation of the deductive strategy, and the method for collecting information refers to data and information in the databases which examines the process of ethnic conflicts in Iraq during the period of 1960 and beyond. To organize the research, first, the theoretical approaches to the relationship between federalism and ethnic conflict are illustrated and then using data and information in databases, the impact of federalism on ethnic conflicts and the process of reducing violence and ethnicity in Iraq will be investigated between Kurds and Arabs.

\section{The Concepts of Ethnicity and Ethnic Conflict}

The term ethnicity was inserted into the social sciences by the American sociologist William Sumner. He defined ethnocentrism as follows "put your culture's values and identity at the heart of judging others (As cited in Bicubic, 2015, p. 3). In this definition, it was intended to make your culture better than all other cultures. From the term ethnicity, two concepts are derived: ethnic group and ethnicity. The term ethnic group and ethnicity are often used interchangeably, but there are differences between the two concepts. An ethnic group is defined as "a community that is among the larger communities that have a descent, past, and history, and they focus on one or two symbols as signs of their unity" (Smith, 1986, p. 16).

Smith uses the term ethnicity for an ethnic group and expresses six characteristics for it. These features include common values, legendary about common descent, an element or components more than a common culture that includes language, and religion, and it belongs to a particular territory, and a common historical background that creates a sense of affiliation for an ethnic group (Smith, 1986, p. 21). According to Max Weber, "ethnicity relates to the feelings of an ethnic group that is consciously developed by the members of the group for its solidarity." (Stone, 1995, p. 393). In fact, ethnicity is a sense of loyalty to people, specific cultural groups or territories. This term is complicated because it has both racial and cultural character.

Also, Rex claims that language, religion, land, culture, and common traditions are used by a community of people to identify themselves as an ethnic group, while ethnicity does not have a physical existence, and it is only a social feeling that this sense creates a sense of unity in a social group (Rex, 1996, p. 88).

\footnotetext{
${ }^{1}$ Many theorists have tried to define ethnic protest, among them Susan Olzak, (1998. P. 178-188) defined as "collective actions in pursuit of collective ends by groups organized around some feature of ethnic identities such as skin color, language, regional location, or customs." Thus collective actions by organized groups are highlighted as the benchmark. Besides, Christian Gobel and Lynette Ong (2012. P. 34) stated that "ethnic protest despite being united by their ethnicity, protest crowds encompass a wide array of social groups (heterogeneity) and that their protests are frequently aimed against the system." Here other social groups are also included. Still, the use of term "ethnic protest" as has been used in this paper is not clearly defined in the above definitions. Thus, ethnic protest includes any unsatisfactory action originated by ethnic minorities, echoing complaints to the existing system of governance and sociopolitical order inside a single state. Hence, the complaints hold various ethnic-based demands expressed more in political messages.
} 
From the arguments discussed above, this conclusion is reached; what is related to an ethnic group and ethnic solidarity is different from time to time and from place to place. The consensus on a specific political course is not possible in this case. However, the question that arises in this regard is that; what is actually an ethnic conflict? And how does it come about? This concept usually implies an internal conflict in which ethnic groups have entered into conflict with one another. This term covers a wide range of political and social issues. Two types of ethnic conflict can be identified: One, the conflict between ethnic groups and ethnic civil wars. Such conflicts may include essential issues such as political, social, economic, cultural, religious, territorial and linguistic issues. The second is the clash between ethnic groups and the government, which provides a platform for the decrease of legitimacy and authority of the state. In this context, Paul Brass (1991) and Donald Horowitz (1985) consider the spread of ethnic conflicts as the result of government policies. Many factors contribute to those conflicts, which include: unequal distribution of resources and social interests by the government, the domination of an ethnic group on other ethnic groups, as well as the inequality of power and influence between ethnic groups and the central government (Brass, 1991, pp. 204-207).

In fact, these factors are the cause of crises and civil wars stemming from ethnic conflicts in a country. History is fraught with continuous and numerous ethnic conflicts. Indeed ethnic conflicts can also be classified according to their magnitude and severity. Based on this factor, Kreisberg (1993) classifies ethnic conflicts in terms of controllable and uncontrollable. In an uncontrolled pole, there are conflicts that the parties involved are not ready to establish peace and reconciliation, and thus the closed circle of violence rotates continuously. In a controlled pole, the parties engage in institutionalized and acceptable forms of confrontation and use conventional negotiation to resolve conflicts and avoid violence.

Based on the above arguments, it should be noted that ethnic conflicts are neither natural nor simple phenomena, but it is a constructed phenomenon and the result of the deliberate choice of individuals or leaders and their followers.

\section{Federalism as the System of Government}

Federalism, as a form of decentralized government, is a kind of legal-political system in which political power is divided vertically between the central government and its sub-divisions. Hence, the federal system, while preserving the diversity of components constituting political unity through a universal constitution, at the same time it means both a structure and a method of government that establishes the unity on the basis of understanding and consent (Wheare, 1964). According to Ostrom (1989) and Elazar (1987), the term Federalism means covenant which originated from the "Foedus" Latin term. As stated by Börzel (n.d, p. 4) federalism "refers to a spatial or territorial division of power between two or more levels of government in a given political system". Riker (1964: 11), quoted by Fillippov et al (2004: 5), provides a definition for federalism which in a state that in "two levels of government rule the same land and people; each level has at least one area of action in which it is autonomous; there is some constitutional guarantee of the autonomy of each government in its own sphere".

Also, one of the most important aspects that distinguish this type of state structure of other kinds of political systems is that in these systems, none of the central and local states alone have the power to restrict the authorities of the other or expand them. In a federal government, the independent rights of the government of the parties are mutually agreed upon by the parties (the central government and the state). Furthermore, the nature of federalism is established on the base that every federalist system requires a minimum of cooperation from different levels, and only in such a way this political system is capable of acting, especially in dealing with economic, environmental and social issues (Watts, 1999). Therefore, federalism is a solution to the controversial issues crop up in ruling a state which includes various ethnic groups, taking into account the historical, social, geographic and economic considerations of each region, which seeks to link people and political units in a permanent alliance but limited on the basis of mutual reciprocity. 


\section{Theoretical Debate}

Federalism is a theory of autonomy and division of power that in term of structure continues to exist (Riker, 1964). Throughout history, states and politicians have been using federalism to rebuild multiethnic countries after removing dictatorial regimes. For example, the command of international coalition forces by the leadership of the United States after the Iraqi liberation operation in 2003 has paved the way for a reformation of Iraq in the form of a federation. The arguments about ethnic conflict and federalism are based on two general approaches; alongside there is a middle ground one. From the perspectives of the first approach, the creation of a federal system will slow down and reduce ethnic conflicts in multi-ethnic countries, and on the other hand, the other approach believes that federalism will exacerbate ethnic conflict. Meanwhile, there are some but small in the number who claim that federalism neither increase nor decrease ethnic conflicts. In the following sections both the arguments of opponents and proponents of federalism as a system for reducing or increasing ethnic conflicts and the middle ground have been discussed.

\subsection{Federalism and the Decreasing of Ethnic Conflicts}

Many justifications have been provided by those who support ethno-federalism or better known multi-ethnic federalism such as Horowitz (1985), Hueglin \& Fenna (2015), Matthias Basedau, (2011), and Yash Ghai (2000). They argue that adopting federalism in ethnically divided societies can assist to manage ethnic conflict which can otherwise turn to violence and untimely end up in expand to other states. By enabling local authorities to have a degree of autonomy in administrating their affairs political conflict can be managed. They claim that no other system can provide better space for ethnic groups to exercise their rights than federalism. The strength of federalism as a tool to conflict management manifests itself in the establishment of sub-units that can make ethnically heterogeneous states more homogenous. Furthermore, they argue that the advantages of federalism as a suitable system for multi-ethnic societies can be investigated from several angles. For example, a federal arrangement can establish self-government for ethnic groups which is expected to reduce conflicts given that the sense of security is available for them. Moreover, the relationship between ethnic groups can be pacified through the contribution of federalism, since it can preserve minorities' languages, culture, and other characteristics. In below under separate sub-section, the views of several scholars who believe that federalism reduces ethnic conflicts have been articulated.

\subsubsection{Bureaucratic Institutions}

The formulation of bureaucratic institutions can raise the possibility of managing ethnic conflicts democratically. The emphasis on bureaucratic institutions aimed to assist mitigates ethnic conflicts, avoid civil wars, and resolve violent conflicts. One of these theorists, Donald Horowitz, in his book, Ethnic Groups in conflicts (1985), underlines the highly ethnically segregated societies in areas, for instance, Asia, Caribbean, and Africa such as Sri Lanka, Nigeria, and Guyana. He uses a long interethnic conflict in Nigeria as a case study. Horowitz describes different mechanisms that have been used to stop conflict and ethnic violence during these eras. One of these mechanisms is the granting of more regional autonomy to ethnic groups in Nigeria. For example, at the beginning of the crisis that accompanied by the independence of the year 1960, the country was divided into three significant heterogeneous regions dominated by the largest ethnic tribes. By 1983, violence, hostilities, and the deaths of more than a million people, have changed the Nigerian federal structure. As a result of the violence and the civil war, the three central regions were replicated in nineteen regional autonomous states. Horowitz claims that attempts to create homogeneous and one-to-one regions, which were in contrast to the three large non-homogeneous regions, reduced inter-ethnic conflicts. Since these groups have found this ability to have more control and autonomy over their specific regions and were often differentiated concerning linguistic differences, this ethnic crisis has 
been unexpectedly reduced. He stated that "the expansion of the states dispersed some of the disagreement into smaller local communities and disintegrated it" (Horowitz, 1985, pp. 612).

He hypothesized that the formation of new states in the country has led to the emergence of new conditions that led to the rise of non-violent intra-ethnic conflicts in these areas. As the development of political parties and the creation of competition for new state-owned jobs and opportunities, have increased in new regional bureaucracies (Ibid, p. 598).

Additionally, Kalin, (2000, p. 3) considers political institutions as helpful tools to manage ethnic conflict depending on the capacity of those institutions to solve ethnic problems via their routines, mechanisms, and procedures. Also, Hueglin \& Fenna (2015), argue that, by opening a window for federal institutions in sternly divided societies, the role of those bureaucratic institutions can be seen easily in aiding the reducing ethnic conflict. However, it depends on the configuration of those institutions. Matthias Basedau, (2011) in his study (Managing Ethnic Conflict) found that, having respective institutions will guarantee a fair and adequate share of representation in political institutions for ethnic groups; such as, a relative representation electoral system or a federal state structure in a more positive or integrative manner, he goes on to argue that, cooperation and coordination between different ethnic groups can be actively encouraged by the establishment of power-sharing agreements, it means institutions. So, the main argument is that powerful institutions provided in the federal system can reduce conflicts based ethnically. ${ }^{2}$

\subsubsection{Diversities}

This group of theorists sees the strength of federalism to reduce ethnic conflict in providing equal opportunities for different ethnic groups with their diversities and recognize their characteristics. One of those theorists is Yash Ghai, who views federalism as an arrangement that will make all regions enjoy equal power and the equal relationship with the central government (Ghai, 200o). Ghai believes that autonomy can play a fundamental role in resolving differences in the existing relations between different communities in multi-ethnic states (Ibid, p. 484). Also, federalism can disperse conflicts and, in particular, is a mechanism for maintaining and upholding the culture and values of a society (Ibid, p. 484).

Ghai explains how federalism can succeed in solving ethnic conflicts and preventing civil wars and unrest. The leading player who can bring rival groups closer together is their shared interests. He accepts that the definition or recognition of similarities shared by all ethnic groups within a state or geographic region can be difficult. But he explains that some of these interests or shared links identified by all groups or sects are the right of other groups to protect their own culture, language, and religion. According to him, the secret of autonomy is the identification of commonalities, and this condition is the benchmark of its success (Ibid, p. 485). He suggests that autonomy and federalism offer better prospects for protecting the culture, language, religion of different ethnic groups in a country, and resisting the policies and actions of the government's homogenization (Ibid, p. 494).

Also, Fearon, (1998) in line with above argument argues that, federalism system by arrangement of issues pertaining to ethnic groups can reduce ethnic conflicts, such as, autonomy in educational system will protect the group's identity; law enforcement and judiciary rights in pursuing their ethnic matters can preserve the survival of a group physically; granting a degree of self-determination in economic can satisfy a group in terms of prosperity. Hence, if ethnic groups are free to worry about their diversities, the will of ethnic resistance is diminished. Therefore, the point is that the conflict raise due to differences between ethnically divided groups, so if a mechanism exists that can accommodate those differences, the chance of conflict will reduce significantly. ${ }^{3}$

${ }^{2}$ For more see (Hueglin E Fenna, 2005; Burgess E Pinder, Eds, 2007; Levy 2007; Wolff 2010).

${ }^{3} \mathrm{See}$ (Mason, 200o; Keil \& Anderson, 2018; Anderson, 2013). 


\subsubsection{Extending political power}

The descent of political power from the central to local regions can decrease ethnic conflict in the view of this group of scholars. In a joint study by Donald Rothchild and Caroline Hartzell titled "Security in Deeply Divided Societies: The Role of Territorial Autonomy," they expressed their support for the idea that federalism could play an essential role in reducing ethnic conflicts. They looked at three different forms of territorial autonomy in their research. These three forms are centralized federalism (centralized), decentralized federalism (decentralized) and regional autonomy.

For them, by extending political power to the subordinate sectors of the state, territorial autonomy can give assurances to minority groups whose ability to control social, cultural and economic issues in achieving their identity and their shared interests are paramount. If issues such as language, education, and the achievement of civil service and social services are viewed by a community to ensure its survival, then leaders and members of that community must seek their control over these trustworthy issues (Rothchild \& Hartzell, 1999). Thus, they conclude that territorial autonomy or the centralized form of federalism guaranteed by the representation of minority groups in the center can be used as a conservative approach to conflict management. They believe that "if territorial autonomy can be used to ensure the groups are strongly divided in societies, about their security and their ability to exercise authority and power, then this arrangement can be helpful in establishing consistent sustainable compromise policies" (Ibid, p. 269).

Moreover, Lijphart in his study (1977) suggests that a useful remedy to ethnic conflicts is altering their incentives through alteration and creation of political institutions that extend political power for ethnic groups, he claims that, through this extension of power the violent conflict will be channeled to the sphere of politics game on the base of legitimacy. Also, in a separate work Lijphart (2002, p. 1300 concluded that delegate rule-application and rule-making, put it in another way, executive and legislative power, to federal institutions and lower levels are best opportunity to create autonomy for a group. Hence, the non-accumulation of political power from the central and granting local states with a degree of political power is the benchmark of decreasing ethnic conflict. ${ }^{4}$

\subsubsection{Encourage to choose peace over conflict}

In the view of other scholars, federalism with its mechanisms can encourage ethnic groups to step toward peace rather than war, given that tools are set up to address the issues concerning different ethnic groups. In a paper entitled "A New Look at Federalism: The Import of Institutions" Nancy Bermeo argues that federalism has helped countries to protect peace and prevent violence in industrialized countries and Third World Countries. He explains that federalism has helped in sustaining unified and democratic countries in confronting the possible segregation of regional minorities (Bermeo, 2002). For Bermeo, the development of federal institutions has provided more opportunities and incentives to elites in the ethnically divided area, to solve their differences by finding political solutions rather than choosing to arm conflict.

Besides, Bermeo also discusses how federalism has been accompanied by the development of various levels of government between the center of government and its districts and regions. The federal system provides more layers of government and therefore creates more areas for peace accords. Also, these systems at least offer some regional elites a greater chance of existing political institutions. With these incentives, there can be fewer armed insurgencies in the federal government (Ibid, p. 99). The layers that Bermeo refers to are various bureaucracies or institutions created through the implementation of federal structures such as community service, judicial or legal branches, law enforcement or security, commercial sectors, and other types of government functions. As a result, the probability of an armed conflict in federal systems is far less than dictatorial regimes, since members of all ethnic groups have more opportunities to participate in these different levels of government (Ibid, p. 99).

${ }^{4}$ More on this in (Stepan, 1999; Hannum, 2004). 
William Riker (1964, p, 114) emphasizes the bargaining agreement between the central government and the regional states, and he put only two preconditions for a peaceful coexistence of different ethnic groups under a federal system, first, the degree of willing from the central government to give a degree of autonomy to regional states in managing their affairs, and second; to what extent ethnic groups are prepared to give up their independence for the sake of peaceful coexistence. Also, Carl Friedrich (1968) in a more detailed work emphasized on the significance of communication between different ethnic groups in ethnically divided societies; he argues that federalism should be considered as a mechanism whereby different ethnic groups or political communities agree to negotiate decisions and solutions on common issues. Accordingly, their point is clear, as long as problems concerning from different groups are taken into consideration, ethnic groups' desire to solve outstanding issues through peaceful means are more preferred. ${ }^{5}$

\subsubsection{Institutional collaboration}

Some scholars on top of them Elazer (1991) argues that federalism on the base of institutional collaboration is the best solution for societies divided on the base of ethnicity. His theory which is named "collaborative federalism" is based on a non-hierarchical and non-centralized model. According to him, Federalism is the ongoing process which can make national goals achievable, not only by exercising power by the federal government, or by functioning of sub-national units via the help of the center, but by governments work collectively. In this process through formal and informal negotiation, autonomous or semi-autonomous actors interact with each other, and jointly creating rules that determine the structure of their relationships and the methods of actions and decisions that brought them together. Thus, according to him resolving conflicts and problems requires the real engagement and commitment of all orders of governments.

Furthermore, consistent with Smith (1998), the dynamic mechanisms to function federal system in ethnically divided societies is collaborative governance, this process involves different stakeholders (different ethnic groups) in the process of decision making in a complex community. The characteristics of collaborative governance include; the will of the central government to forum institutions that can contain ethnic groups that are directly engaged in decision-making, the aim is to arrive at a collective decision via agreements based on mutual understanding and compromise. Hence, for them, the role of collaboration in governance is essential in ethnically divided societies. ${ }^{6}$

All in all, as discussed above for some scholars, federalism is a potentially practical and useful system to establish an institutional arrangement that can accommodate the demands of ethnic groups and reduce ethnic conflicts within ethnically divided societies. By granting ethnic groups to practice a high degree of self-government over essential and sensitive issues such as language, education, and religion, federalism at the central level removes these as sources of conflict, by this means reducing ethnic tensions across the system. Sequentially, by giving a degree of control to ethnic groups over affairs of emotional concern may assist reducing enthusiasm for separation and protect the territorial integrity of the state. However, this is easier said than done, given that, in societies that have experienced a history of conflict and unrest, a kind of violent culture is the outcome, while federalism is the result of a long history of experience in governing, hence imposing this system on a society that has no culture of democracy may resulted in backlash, and the implementation of federalism would remain only as ink on paper.

\subsection{Federalism and Increasing Ethnic Conflicts}

Many of these theorists who look at federalism with suspicion, and view federalism in many cases results in greater segregation and ethnic violence argue that one of the main problems federalism

\footnotetext{
${ }^{5}$ View (McGarry and O'Leary 2009; Hechter 2000).

${ }^{6}$ See (Kincaid, 2017; Rocher, E Gilbert 2010; Keil, 2012).
} 
faces is the inability to establish peace in limited ethnic conflicts and prevent separatist movements; while federalism is trying to develop a multi-ethnic community in a fully defined geographic boundary. Their skepticism partly related to the vulnerability of federation on the base of ethnic to fragmentation. They provide several arguments in support of their claim that the use of federalism as a tool to solve or manage ethnic conflict is unsustainable. The unfeasibility of making administrative and ethnic boundaries go well together is one of the main problems. This fact leads to result in conflicts and tensions in the relationship between and among local/regional minorities and majorities.

Furthermore, according to them federalism on the base of ethnic conflict can foster ethnic secessionism, mobilization, and contribution of disputes. Federalism provides a territorial and institutional basis to ethno-nationalist groups. For instance, territorial autonomy offers comprehensive support for separation through equipping ethnic ethno-nationalist movements with borders, cohesion, group identity, parliament, government, leadership and support from external. All this increase the demand for more autonomy. Similarly, a combination of territorially distinctive segments and federalism's grant of partial autonomy sometimes provides additional impetus to demands for greater autonomy; when the centrally-situated or centralist-oriented conflict group refuses these demands, secession and civil war follow. In following under separate sub-sections, the views of several scholars who believe that federalism increases ethnic conflicts have been investigated.

\subsubsection{Secession}

Fear of separation of one or more than one local states is one of the main concerns in the federalism system. Michael Hechter is one of the thinkers who is addressing the major dilemma facing governments that trying to create a federal system. Hechter published a wide-ranging article on the policies of colonialism, nationalism, and ethnic societies, and addressed the issue of the weaknesses of decentralization and federalism. In his work, "Containing Nationalism," he argues that federalism creates a contradiction. In other words, since federalism, in its various forms, offers more political power and, in many cases, economic power to minority groups, which tends to increase the likelihood in those groups to full independence or separatism. Establishing a federation will shift some of the functions of government and central resources towards the lower parts of the regions. The federation may provoke a nationalist conflict, and since it can provide support and resources to the national potential leaders' disposal, it can mobilize and equip them for nationalism movement (Hechter, 2000).

Hechter brought Pakistan's federation as an example, which ultimately sought the emergence of a separatist movement in the eastern regions, which lasted from 1967 to 1970; this led to the loss of Bangladesh. Hechter also referred to the dissolution and disintegration of the Soviet Union and Czechoslovakia, which resulted in a symbolic event which is the collapse of the Berlin Wall in 1989. He claims that these systems failed because the center had a lot of power and with force or hegemony it prevented states from achieving autonomy. Perhaps the best contemporary example related to this issue is the former Yugoslavia. In this case, a strong central power tried to prevent and control the nationalist tendencies of its various republics from 1948 to 1991. Hechter stated that "those countries were held together by a structured discipline that was implemented through federal central government resources, clearly designed to calm the disputes between member nations" (Ibid, p. 149).

What is more, Roeder, (2007), in his study found that there is a reason to expect that federalism on the basis of territorial decentralization among ethnic group boundaries instead of softening ethnic conflicts harden them. Any degree of autonomy less than completely independence may not only reduce ethnic identities but harden them, given that establishment of the administrative setting legitimizes the group's won claim on the territory, because identities on the basis of ethnic are being politicized, forged and get fastened attached to the territory, which finally may end up in growing the demand of secession. In line with this, Brancati (2006) claims that regional parties can be 
strengthened by decentralization, and this increases the likelihood of the future agendas of secessionist due to the increase of mobilization capacity. Hence, those provided capabilities for ethnic groups by decentralization, equip them with enough resources to formulate the agenda of secession more feasible and legitimize their demand on the level of the international community. The point is that, although essentially federalism adopts to keep ethnically different groups together, the nature of federalism in the view of those theorists leads to disintegration.

\subsubsection{Secessionist Violence}

What is obvious is that pushing from local regions to achieve more autonomy and resistance from the central government will end up in violence. Walker Conner is a prominent scholar in the field of nationalism and the problems of creating a federal system and ethnic conflicts. He believes that most of the failures of the federal system are due to the recognition of ethnic groups along with the acceptance of ethnicity and their nationalist ideas. In his article entitled "The Politics of Ethnonationalism" Conner points out that ethnic minority groups are demanding autonomy or independence, faced with opposition from dominant state power. The federalized powers show resistance to the right to self-determination, and it increases its powers and responsibilities to protect the country, repress riots, guarantee the security and tranquility of the country and defend the territorial integrity of the state (Connor, 1973). For Conner federalism creates a distant form, because groups that try to achieve autonomy or self-government are faced with opposition and compulsion, and this fact creates more violence and more separatist movements. The contradictory nature of federalism makes federalism unable to eliminate the desire of ethnic minorities who demand independence through separatist and violent efforts.

Another theorist who suspects federalism in reducing ethnic conflict is Hale (2004) he argues that dividing the country on the base on ethnicity may lead to civil war or collapse of the state as a whole. Furthermore, Bakke and Wibbels (2006) investigated the arrangements of power-sharing in a federal system based on inequality, fiscal decentralization, and the ethnic framework of federal units. They came to an exciting conclusion while attempt to explain conflicts. Based on their research, when high-income inequality combined with ethnic heterogeneity, causes to more conflict, and the level of economic progress of the ethnic regions determines the effect of fiscal decentralization. So the potential demand for more autonomy is the primary source of violence in ethnically divided societies.

\subsubsection{National Movements}

National identity is a major tool for the leaders of ethnic groups to use it in pushing towards more autonomy. One of the famous academicians who view federalism as a mechanism to create national movements is Jack Snyder; he argues that federalism often leads to the creation of institutions where elites or tribal elite of ethnic minorities pursue the interests of their ethnic minorities and prefer them on the rights of others in the federal state. Federalism provides proper incentives for the elite to mobilize broad backing and support for ethnic issues (Snyder, 200o). Snyder claims that the role of federalism, in fact, is to undermine the power of the central government and to strengthen the national conflict between different ethnic groups.

He goes on to say that the decentralization of power encourages the ethnic groups that are fighting to achieve independence and this increases violence. He continues to say that "Political decentralization is involved in the rise of violent nationalism and leads to a diversion of liberal reforms"(Ibid, p. 206). Snider argued that the decentralization of political resources and political power because it leads to strength of ethnic groups or nationalist movements, it affect the ability of central government and this causes a weakening of the central government and a diminution of its influence over its components (Ibid, p. 210). ${ }^{7}$

${ }^{7}$ For more see (Nordlinger 1972; Lorwin 1968; Cornell 2002; Brubaker 1996). 
In line with the above argument (Duchacek, 1975) claims that knowing that segmented states are not homogenous completely, territorial decentralization leads to the formation of new minorities, and these, in sequence, creates the possibility of being suppressed and disadvantaged. Milanovic and Sambanis (2005), concluded that, when a particular region treated differently on the base of ethnicity, this differ administrative unit enlarges the degree of discrimination of that unit in comparison to the other groups or the rest of the state, at least regarding ethnicity, and this ended up in increase of national movements to gaining more autonomy till sovereignty. Put it concretely; more independence means an improvement of the position of minority in bargaining, which can raise the level of demand from more autonomy to full sovereignty.

\subsubsection{Politics of difference: increase of ethnic political diversity}

The effects of federalism in multi-ethnic societies do not end in only separation or violence, but also it affects the domestic political system; this is according to scholars who suspect federalism as a tool to reduce ethnic conflict. The electoral system and parties on the level of central government would divide between ethnic party identities. It increases politics of difference, in line with this Haysom, (2003, p. 225) stated that "those who seek popular support must strive to be the most authentic and 'ethnic' of the candidates or parties, and the most resolute in asserting the ethnic interest as against the 'others."

Besides, J.A.A. Ayoade, (1987) argues federalism on the base of ethnic conflict is a poor institutional mechanism to fulfill those purposes that federalism has been established for at the first place. It seems federalism is in contrast with them. Even when federalism is not based on ethnic, still is not a stable form of government. They continue to claim that almost every established government on the base of ethnic has had sooner or later the challenge of separation from one or more than one of constituents regions. Furthermore, Alemante, Selassie (2003, p. 85) argues that the marriage between ethnicity and federalism, however, appeals to numerous difficulties to be workable or viable. The nature of the system depends on the division of citizens on the base of ethnic lines institutionalizes those lines of division. Thus, ethnic divisions have little possibility to disappear over time once materialized in this way. When political identity is formulated by the state through the deliberate use of ethnicity, the remaining citizens who did not define their ethnicity will find a distinct ethnic identity. This formal partition of country creates more incentives for members of each ethnic group to take side of its group in each and every issue, whether is it related to local (regional) interests or national ones; this fact also pushes leaders of each group to utilize the political process to achieve domestic legitimacy on the expanse of national goals. Consequently, the different ethnic communities presence alongside, but will not integrate.

All told, as have been explained above, for some scholars, the creation of autonomous ethnic units leads to the institutionalization of ethnic identity which merely serves to deepen and harden these divisions within ethnically divided societies. Through federalism and institutionalization of ethnic identity, the demands for separation increases and the desire and willingness of autonomous ethnic units to go it alone, in addition, equip them with enough institutional resources to mount a successful separation. Thus, federalism and decentralization of power increase both the claim for secession and makes easy its supply.

Even though those above arguments are supported by evidence, the literature of federalism is rich enough in examples that federalism has managed conflict in ethnically divided societies. Even the case of secession it was viewed as a proper solution based on the consents of both sides to end conflict such as Sudan. Also in contrast to their claim, the case of The United Arab Emirates is a typical example that federalism brought separated regions together and created a national identity, although their regions are not totally ethnically divided the national identity of The United Arab Emirates was not exit before adopting federalism. 


\subsection{The Ineffective Case of Federalism on Ethnic Conflicts}

While reviewing the literature of ethnicity in divided societies on the base of ethnicity, a considerable amount of works try to find the causes of ethnic conflict and how it can be prevented. However, the literature of ethnicity is not empty of the works which argue that the existence of ethnic groups in a society does not lead to ethnic conflict ultimately. A school of recent studies (Birnir 2007; Chandra 2005; Ishiyama 2009) found out that ethnic diversity in plural societies will not eventually increase the likelihood of ethnic conflict. Chandra 2005 argues that most of the earlier studies and recent ones assumed that ethnic diversity and ethnic politics would naturally end up in violence. In both policy literature and academic ethnic diversity has been labeled as a bad phenomenon and is considered a problem that needs to be solved. But, newer works have underlined that most of the ethnic groups in diversity societies live together peacefully, whether they are politically mobilized or not. He continues to claims that those societies were homogenous before, federalism is adopted to govern the country more properly, since some countries are too big to be ruled directly from the central government such as the US.

Furthermore, Ishiyama (2009) in his work titled "Do Ethnic Parties Promote Minority Ethnic Conflict?" concluded that ethnic groups engaged in ethnic conflict does not depend on political institution or other related variables, ethnic groups independently increase ethnic conflict is free of evidence, many societies live together peacefully before and after the rise of ethnic groups and this result does not depend on political structure of the state. Also, Birnir (2007) claims that ethnic group (ethnic attractors as she refers to) try to achieve political power through peaceful means. Their aim is to gain leverage for a constituency, make their voices heard, and act in accordance with their interests. In return constituents prefer ethnically based parties by utilizing ethnic identity, they vote for a party that acts on behalf of a particular ethnic constituency. However, this could be done, when a non-ethnic group member vote for an ethnic group or vice versa, an ethnic constituency acts on behalf of a non-ethnic member. This indicates that the existence of an ethnic group does not ultimately wind up in ethnic conflict.

These findings raise a question whether solution actions such as federalism system to share power among ethnic groups is effective at all. Thus, in contrast to the main schools of thought, the effect of functions of federalism can remain only as a model of governance in the lens of some other scholars. However, their arguments are hardly credible given that federalism does affect internal political system which causes in power expansion of regional units within the state, and this depends on the form of power-sharing in the structure "constitution." Hence, adoption of federalism may not affect some countries that are homogenous before, but in many other heterogeneous societies, power-sharing works well knowing that the source of conflict is centralized power from the central government.

As has been illustrated in the above sections, there is unending debate whether federalism can be an effective system to reduce ethnic conflict or the other way around, or the system is ineffective at the first place. In the following sections, the impact of federalism on the ethnic conflict in Iraq is discussed under the light of the above theoretical debate.

\section{Overview of Ethnic Conflict in Iraq}

Iraq is one of the Middle East and the Persian Gulf states founded in 1920, following the collapse of the Ottoman Empire, as a result of the colonialism of England. Most of the Iraqi population is composed of two major ethnic groups namely Arabs and Kurds, and religiously from Shiites, Sunnis, none of which have played an effective role in establishing this country. The geography of Iraq from a religious perspective is divided into two regions: (a) the southern half of Iraq, from Baghdad to the south, in which Shiite Arabs are concentrated; (b) the northern half of Iraq, where the Sunni Arabs in its Western parts and the Sunni Kurds are located in the East. The Iraqi population is ethnically mixed with more than 71 percent of Arabs, 19 percent of Kurds and 2 percent of Turkmens, and other 
small minorities such as Akkadian, and Assyrian. Accordingly, the composition of the ethnic, religious and linguistic fabric in Iraq is in a heterogeneous structural situation. During the period of monarchy which lasted 37 years, in order to preserve the territorial integrity and promote the notion of nationalism, there was a great deal of use of violence and the organized oppression, and this crackdown policy continued after the bloody coup of Abdul Karim Qassim in 1958 (Mohammed, 2013).

In the Post-2003 US invasion of Iraq, Turkmens, Kurds, and Arabs make up the majority of the population, but the Turkmen have had a very few political, social and economic impact due to small inhabitants, but ethnic Arabs and Kurds, because of the massive masses of the population, have been struggling to expand their sphere of influence. On this basis, Iraq has always faced a major ethnic cleavage, the structural differences between the Kurds and the Arabs, which since the beginning of the founding of this country has been a significant blow to the creation of a single and united nation. In other words, the violent conflict between the Kurds and the Arabs is one of the most persistent and regular political characteristics of Iraq since the beginning of its independence, so that the Kurds have been fighting since the 1920 or have been continuously negotiating for self-determination with the central government (Rogg \& Rimscha, 2007).

Basically, politics in Iraq, in particular, before the fall of Saddam, has been mixed with the suppression of identities, regardless of the ruling ideology. In particular, the Kurds, who have faced many restrictions and pressures and the denial of power throughout Iraq's history, especially during Saddam's era. Therefore, the Kurds were not satisfied with the policies of the central government. Iraqi Kurds have not only been distinguished from the ethnic, cultural, and historical components of Iraqi Arabs, but the policies of central governments in Iraq have always been in the direction of excelling Arab culture and negating Kurdish culture and language. The struggle of Kurds for achieving autonomy or independence has been ongoing since the creation of Iraq (Gunter, 2007).

\section{1}

\section{The Nature of Federalism in Iraq}

According to the First Article of the Iraqi Constitution, the Iraqi Republic is an independent, sovereign state, a Parliamentary, Democratic and Federal Republic. Article 4 emphasizes that Arabic and Kurdish are the official languages of the country, and Iraqis have the right to teach their children, in Turkmen, Assyrian, Armenian, and any other language, in their educational institutions, according to the principles of education. Given the demographic composition of Iraq, ethnic pluralism policy has been considered the most crucial indicator of Iraq's constitution. National identity is defined concerning the civil rights of the state, not on the base of the cultural components. On this base, the social community is one of the citizens who has joined together through common political rights and commitment to democratic practices. In this sense, the nation is a political concept, distinct from ethnic nationalism, which considers the nation as a racial and reproductive social one (Alsamee, Wahab \& Yusof, 2017).

In this framework, we see a kind of return from the idea of a single national culture and monolingualism to accept the cultural and linguistic multiplicity within national unity; in other words, the shift from the modernization of identity, which followed the formation of the Iraqi government in 1920-2003 to Postmodern identity and acceptance of other intellectual forms, even within the framework of culture, race and language. The system of federalism in Iraq is the type of ethnic federalism, because, according to paragraph 1 of article 114 of the permanent constitution, Iraqi federalism is ethnic federalism due to the recognition and establishment of the Kurdish-dominated Kurdish region. This system of federal government has not existed before in any federal system with only one regional government and one central government (McGarry \& O'Leary, 2007).

\subsubsection{Separation of powers}

In this regard, Article 108 lists monopoly powers and responsibilities of the federal government, and Article 112 mentions the responsibilities and powers shared between federal and regional authorities. 
However in reality the is only one Kurdish region and the Central Government. According to Article 112 , it is stated that anything that is not specified in the exclusive authorities of the federal government, is left to the authority of the regional governments and provinces. In addition, according to part 1 of Article 118, it is on the authorities of the regions to amend their constitutions if those amendments do not interfere with the exclusive authority of the federal authorities in the constitution. Also, consistent with the same article Section 4, federal offices of the regions are formed at embassies and diplomatic consulates to pursue cultural, social and development affairs, which is a lesser-known heresy in the theory of federalism, because the regions have been allowed to have offices and agencies at embassies of Iraq outside the country (Ibid, p. 687).

\subsubsection{The Powers of the Kurdistan Region}

In this framework, according to Articles 112-119 and 137, the laws are foreseen to be the first: that has recognized federalism in the Kurdistan region; secondly, the regions are governed by the general structure of law in this country. Accordingly, Article 114 recognizes Kurdistan as a federal state, and Article 137 identifies the continued implementation of the laws of the Kurdistan Autonomous Government if they are not in contrast with the constitution. Article 117 allows the regions to determine the structure of the regional government and the powers of the regions by formulating their laws. According to Article 118, Paragraph 1, regional governments are authorized to exercise executive and judicial powers outside the exclusive jurisdiction of federal authorities, and in the Second Paragraph of this article, the regions are permitted to amend their laws if they are not in contrast with the exclusive authorizes of the federal government in the constitution. In the Third Paragraph, the fair distribution of federal revenues will be given to the regional governments and in the fourth paragraph, as has been coded, is a kind of low-level heresy. Finally, in the Last Paragraph of this article, the establishment of internal security forces has been delegated to the government of each region. Article 119, Section 2, has delegated broad administrative and financial authority to organized regions and, in accordance with Paragraph 5 of this Article, the Provincial Council, and its finance is independent of any ministry or its related entities (Kttafah \& Hassan, 2017).

Knowing that the Kurdistan region is the only region that has been established in the federal system of Iraq; the authorities and responsibilities are mainly divided between the central government and the regional government of Kurdistan. This kind of forming federalism is unique, because first, to establish a federal union, there must be at least two regions plus the central government, while in Iraq, only the Kurdistan Region is now created as a federal unit. Second, while the apparent feature of federalism is a dual rule or the sharing of power between the central government and the states, this is precluded in Iraq because of the lack of formation of other regions; other provinces besides the Kurdistan Region are treated as provinces of an integrated state. Third, in the Kurdistan region as a federal region there are offices, organs, and legal entities specific to a country, but in the Shiite and Sunni areas, due to not formulation of any other region, the same central Iraqi legislature is legislated by the same central Iraqi parliament, and the president and prime minister are the same presidents and prime minister of Iraq. Fourth, In the federal Iraqi government, the central government lacks "tacit authority" to deal with day-to-day issues. While in federal systems such as the United States, the central government is empowered to approve all laws that are necessary and appropriate for the exercise of other powers on the basis of the "proper and appropriate" clause, this is according to the first paragraph of the first principle of the Constitution. Therefore, like all other federal countries, the federalism system in Iraq has its characteristics which are not in any other federal systems in the world (Ibid, p. 1845).

\subsection{The Impact of Federalism on Ethnic Conflicts in Iraq}

In this section it has been attempted to apply and connect the above theoretical arguments with regard to the case of Iraq and assess their accurateness in the impact of federalism on easing or 
exacerbating ethnic conflict in the country, and find an answer to this question; does federalism hold the key to solve ethnic conflict in Iraq?

Some writers and scholars have been writing about Iraq consistently, anchored in their lookout and experience of the situation in Iraq after the adaptation of federalism, and whether federalism can truly bring stability to the country in terms of politics, security, and economic. A school of them have found out that federalism worked in Iraq and assessed in easing tension (Mohammed, 2013; Mistaffa, 2018; Williams \& Simpson, 2008; Danilovich, 2017). Meanwhile, the others have doubt and argue otherwise (Lockhart, 2014; Saayman, 2013; Cordesman, 2007). Almost all of them investigate the effect of federalism on security such as terrorist attacks or unrest caused by the sectarian conflict between Shia and Sunnis or the system of governance, whether federalism can establish strong institutions, or how can federalism push other minorities to seek separation. However, the current study focus on the impact of federalism on easing or exacerbating ethnic conflict between Kurds and Arabs which is the essential aim of adaptation of federalism in Iraq after 2003. Thus, the Iraqi federation offers an explicit picture of how this paradox plays out.

To understand the effects of federalism on ethnic conflicts in Iraq, three periods which are the period from 1960 to 1991 , the no-fly zone from 1991 to 2003 , and 2005 to present day in Iraqi history were examined. Also, it has been attempted by using various sources and data, show the extent of ethnic violence and tensions in these periods, and the impact of autonomy and federalism on the decrease or increase of ethnic conflicts in Iraq.

\subsubsection{Ethnic Conflicts From 1960-1991}

The starting point for ethnic conflicts in Iraq is 1961. The Kurdish rebellion began in March 1961. It lasted till 1991, during this period several wars occurred between the central government and the Kurdish rebels. From the viewpoint of many scholars, the root cause of these conflicts is the marginalization of the Kurds from political power. Derouen and Heo (2007) argue that the occurrence of these conflicts is not only due to political, territorial and ethnic factors but also factors such as the disputed definition of the state, the regime's vision, and potential threats to social cohesion through efforts to create a limited national identity within the borders of Iraq. Ted Robert Gurr (2000, p. 107) claims that the ethnic conflict between the Kurds and the Arabs from 1960 to 1991 was due to the desire of the Kurds to autonomy and rule over the Kurdish regions, because in the eyes of the Kurds, autonomy protected them from ethnic violence and provided security in their lands. Therefore, due to the lack of federalism and regional autonomy, that can provide Kurds the guarantee of the survival of their identity as a separate identity from Arabs, and exercise of their language and culture. Since the political system of Iraq did not recognize other ethnic identities, the Kurd's demand for autonomy has been rejected, and this fact led to continuing ethnic conflict between the Kurds and the Arabs. The long and violent period of thirty years with the invasion of Saddam Hussein in Kuwait in 1990, followed by the first Persian Gulf War in 1991, entered a new stage and the international coalition brought autonomy to Kurds.

\subsubsection{The Period between 1991-2003}

The Kurdish No Fly Zone on April 8, 1991, by United Nations Security Council Resolution 688 was imposed on the Iraqi regime, which it provided the basis for Kurdish Autonomy and the creation of institutions to influence the structure of the Iraqi political system. For nearly a decade, the Kurds dominated the Kurdish regions, held democratic elections, and created state institutions such as the judiciary and the legislature. Besides, democratic processes led to numerous polls and the formation of new political parties (O'Leary, 2002).

At this point, the rate of ethnic conflicts and violent incidents, as well as the desire of the Kurds for separation and independence, decreased significantly. Concerning the authoritarian system of Iraq, autonomy and the possibility of Kurdish liberation provided political, social and economic 
benefits, and gradually ethnic demands were followed up by the democratic process. Consequently, the methods and tools for pursuing ethnic desires were continuously redefined, in the midst of democratic institutions, despite the negative historical mentality and perception of the threat. This led to limited ethnic conflicts during this period.

\subsubsection{The Period between 2005-to Present}

The Iraqi Constitution passed a national referendum with the votes of $78 \%$ of Iraqis and $99.5 \%$ of the Kurds on October 15, 2005. After the enactment of the Constitution, virtually the violence between the Kurds and the Arabs was stopped, and the violence was mainly between the Shiites and the Sunnis on the one hand and the nationalist groups against the American forces on the other. Compared to the period from 1960 to 1991, ethnic conflicts decreased sharply between the Arabs and the Kurds after the adoption of federalism in 2005 (Wing, 2012).

Many academicians believe that the reducing of ethnic conflicts at this point is due to the implementation of federalism. David Romano, (2004) argues that the Iraqi Constitution recognizes the differences between the culture, language, and history of the Arabs and the Kurds, and brings about the security of the government for the Kurds. We can also point out the arguments put forward by the theoretical charters to prove the claim of federalism and the decreasing of ethnic conflicts. Horowitz (1985) emphasizes the role of federalism in reducing ethnic conflicts through the creation of bureaucratic structures, the development of political parties and the transformation of inter-ethnic rivalries into ethnic groups and in increasing security and stability. Ghai's (2000) focus is on identifying ethnic divisions and protecting culture, language, and religion. Bermeo (2002) thinks that because of federalism, several layers of government have been created, new bureaucratic structures are formed, thereby increasing the chances of an agreement between ethnic groups.

By examining the developments in Iraq, especially in the Kurdistan region, the abovementioned effects of federalism can be seen. After the adoption of the Constitution, the level of security in the Kurdish Federal Region increased, on the other hand, terrorist attacks in other parts of Iraq have become part of the daily lives of the people (Mohammed, 2013, p. 146). Federalism offered the Kurds not only the opportunity of participation but also have a role in shaping the form of the new Iraqi government and its policies. The Kurds utilized their now officially recognized influences to negotiate the outstanding issues with the Central Government such as the fate of Disputed Areas. Kurds participated rebuilding Iraqi government and took the high positions of the government such as the post of new president of Iraq occupied by Jalal Talabani, and other positions including; Iraq's deputy prime minister, Army chief of staff, the finance minister, foreign minister, and many other lower positions (Nader, Hanauer, Allen, \& Scotten, 2016). Thus, the Constitution has become the guarantee of the right of ethnic groups and minorities including the Kurds; this resulted in a desire from the Kurdish part to solve its problem with the central government on the base of the constitution.

Likewise other political system, although federalism has reduced ethnic tensions and has provided security and development in the Kurdistan region, there are still ethnic tensions between the Kurds and the Arabs as a result of the dispute over the control of the cities and districts in Kirkuk, Mosul, and Diyala, and the control of oil resources and Gas is in the Kurdistan region. The dispute over oil selling between the Kurdistan region and the central government resulted in cutting the share of the region in Iraqi general budget in 2014 (Elliott \& beryl, 2012).

The dispute racketed up gradually, and the rise of ISIS in Iraq brought a new political landscape to the country in 2014. Iraq went to the edge of collapse. One-third part of Iraq fell under the control of ISIS. The Kurdistan region took control of the region known as Disputed Areas in the Iraqi Constitution (Gailan, 2017, p. 34). After the defeat of ISIS in Iraq and dispute over the implementation of the Constitution, all this according to the authorities in Kurdistan Region pushed the Kurds to hold a referendum on independence on 25 September 2017 (Mistaffa, 2018). Here we can bring in the argument presented by Hechter, (2000) where he emphasizes that federalism equips ethnic groups 
with enough instrument to seek separation and also Snyder, 200o) who claims that federalism provides ethnic leaders enough support to create nationalist movements. We can observe this by examining the latest events in Iraq; the regional government claimed that, because of the missimplementation of the constitution from the central government. The decision to hold the referendum was made by the Kurdistan region. The rejection of the referendum from the central government and the promises from the center to implement the constitution properly led both parties to sign a new agreement to solve their problem by going back to the constitution (Alaaldin, 2018). Informative is nevertheless to highlight that, a precise examination of the latest events in Iraq such as, the appearance of ISIS, Kurdish referendum in 2017, and the skirmish fights between both sides indicates that federalism despite the fact that, it could not prevent Kurds from attempting to gain independence, but could prevent war between both parties and reduced ethnic conflict, given that, a compromise came about only when from one side the Kurdish region accepts the verdict of the Iraqi Constitutional Court that recognized the referendum as unconstitutional. And from the other hand, the central government showed the intention to solve all outstanding issues according to the constitution. Since, for the majority of the population in the regional government, federalism comes as a second best choice after full independence, given that federalism can provide them more autonomy which can be realistic and have benefits, brought security in the absence of war. Ordinary people can live without the fear of genocidal persecution and a gradually improving standard of living; for elites the prospects of vast riches from the development of the oil resources and a share of Iraq's revenues (Danilovich, 2013). This result proves the hypothesis presented in the current study which claims that federalism despite the fact that as a system of governance it can reduce ethnic conflict in Iraq but not necessarily ethnic protest.

However, in a general term, implementing and espousing federalism in Iraq seems to be a difficult task to conduct compared to other countries with more democracy experience and homogenous societies, because of various reasons ranging from the lack of democratic experience in Iraq's modern history to the presence of very controversial issues. Even though not totally clear what shape will take the upcoming Iraqi federation, it is likely to be a decentralized and asymmetrical federation which resorts to consociational solutions whenever and wherever the process appears to be in problem. Albeit the chances of its success or failure might sound quite equal, it is still early fairly judging the blossoming Iraqi federation.

\section{Conclusion}

Federalism is one of the most important ways of managing ethnic, linguistic and cultural diversity and preventing the emergence of ethnic cleansing. On this basis, governments, especially in democratic societies, by adopting decentralization in affairs, they are trying to offer a peaceful manner of life for ethnic groups. However, the experience of federalism in different societies and its functioning in reducing ethnic conflicts has not been the same. In some communities like the United States, federalism has been an excellent mechanism for managing ethnic diversity and relieving ethnic conflicts. In other societies such as England and Spain, federalism has reduced ethnic conflicts but has failed to mitigate the motives of ethnic groups in trying to achieve independence. Also, the experience of federalism is very different in societies that are still at the beginning of the process of nation-building, and on the other hand, they have diverse religious and ethnic context. However, these communities are also trying to use federalism as a mechanism to reduce ethnic tensions and armed conflicts among ethnic groups.

The results of the study illustrate that in the period from 1961 to 1990 , ethnic conflicts and violence in Iraq have increased sharply. The undemocratic nature of the Iraqi political system and the persistent identity politics has aggravated ethnic divisions between the Arabs and the Kurds in this period. In other words, until 1991, the Iraqi government adopted the policies of identity denial, suppression and systemic violence against ethics. For many years there was an ethnic conflict between Kurds and Arabs in Iraq. The lack of a federal system and regional autonomy for the Iraqi 
Kurds led to massive killings and ethnic violence, at a widespread level between 1960 and 1991, and a large number of Kurds were killed. From 1992 to 2005, with the creation of a no-fly zone, the Kurds experienced a period of autonomy, democracy, and human rights, which resulted in a significant reduction in ethnic conflicts and violence during this period. However, along with this factor, Saddam's fear of international punishment should not be ignored in the face of ethnic violence. In the period from 2005 to present, prior to the emergence of ISIL in Iraq and the division of the Iraqi political system, through the ratification of federalism in the constitution and the creation of federal structures, ethnic conflicts and ethnic violence in Iraq fell sharply.

Although, since 2005, the ethnic and violent conflicts of the Arabs and the Kurds have been significantly reduced, ethnic tensions persist, mainly on issues related to the control of oil and gas resources. But considering that the Iraqi constitution has taken the necessary measures to resolve ethnic tensions, it is very difficult to turn ethnic protests into ethnic conflicts. There have been a number of incidents of ethnic tensions between Arabs and Kurds since 2005, but these tensions have not become violent ethnic conflicts, and have been attempted mainly through the mechanisms provided for in the constitution. Meanwhile, it is worth noting, the latest events such as the rise of ISIS and Kurdistan region referendum, and the resulting tension have been reduced and prevented to spillover by returning both sides to the constitution. Therefore, it is right to say that, federalism although, it could not prevent Kurds from attempting to gain independence, but it has prevented war between both sides and reduced ethnic conflict, however not necessarily ethnic protest. Even though not totally clear what shape will take the upcoming Iraqi federation, it is likely to be an decentralized and asymmetrical federation which resorts to consociational solutions whenever and wherever the process appears to be in problem, this conclusion proves that federalism is suitable to reduce ethnic conflict and solve problems between the central government and regional one via implementing the constitution collaboratively. Albeit the chances of its success or failure might sound quite equal, it is still early fairly judging the blossoming Iraqi federation in the far future.

\section{References}

Alaaldin, R. (2018). Sectarianism, Governance, and Iraq's Future. Brookings Doha Center Analysis Paper, (online), pp. 24-26. Available at: https://www.brookings.edu/wp-content/uploads/2018/11/Sectarianism-governanceand-Iraqs-future_English.pdf (Accessed 5 January. 2021).

Nader, A., Hanauer, L., Allen, B., \& Scotten, A. (2016). Regional Implications of an Independent Kurdistan. The RAND Corporation, (online), pp. 22-23. Available at: https://www.rand.org/content/dam/rand/pubs/researc h_reports/RR140o/RR1452/RAND_RR1452.pdf (Accessed 28 December. 2021).

Alsamee, E., Wahab, H., \& Yusof, Y. (2017). The Emergence of Federalism and its Application in Iraq under the 2005 Constitution. Research Gate. (online), p. 270. Available at: file://C:/Users/Amir/Downloads/DiyalaJuri dicalJournalTheEmergenceofFederalisminIraq.pdf (Accessed 14 December. 2021).

Alemante, G. (2003). Ethnic Federalism: Its Promise and Pitfalls for Africa. 28 Yale Journal of International Law, Vol, 8, No, 4, pp, 51-107.

Anderson, L. (2013). Federal Solutions to Ethnic Problems: Accommodating Diversity. Oxon and New York: Routledge.

Ayoade, J. (1978). Federalism in Africa: Some Chequered Fortunes. Plural Societies, (online), Vol, 9. No, 1. Pp, 3-17.

Basedau, M. (2015). Managing Ethnic Conflict: The Menu of Institutional Engineering. GIGA Working Papers, (online), p. 15. Available at: https://www.giga-hamburg.de/en/system/files/publications/wp171_basedau.pdf (Accessed 19 December. 2021).

Bakke, K., \& Erik, W. (2006). Diversity, Disparity, and Civil Conflict in Federal States. World Politics, Vol, 59, No, 1, pp. 1-50.

Bermeo, G. (2002). The Import of Institutions. Journal of Democracy, Vol.13, No.2. pp. 96-110.

Birnir, J. (2007). Ethnicity and Electoral Politics. Cambridge: Cambridge University Press.

Bizumic, B. (2015). Ethnocentrism. Research Gate, (online), p. 3. Available at: file://C:/Users/Amir/Downloads/Et hnocentrism-VSRBBizumic\%20(1).pdf (Accessed 29 December. 2021).

Börzel, T. (n.d.). EPS Forum: Debating Federalism and Constitutionalism in the European Union. University of Heidelberg, (online), p. 4. Available at: https://www.princeton.edu/ amoravcs/library/eps.pdf (Accessed 22 December. 2021). 
Brancati, D. (2006). Decentralization: Fueling the Fire or Dampening the Flames of Ethnic Conflict and Secessionism?. International Organization, Vol. 6o, pp 651-685.

Brass, P. (1991). Ethnicity and Nationalism, Theory and Comparison. New Delhi: Sage.

Brubaker, R. (1996). Nationalism reframed: nationhood and the national question in the new Europe. Cambridge: Cambridge University Press. Pp, 1-16.

Burgess, M., \& Pinder, J. (Eds.). (2007). Multinational Federations. Abingdon and New York: Routledge.

Chandra, K. (2005). Ethnic Parties and Democratic Stability. Perspectives on Politics, Vol, 3, No, 2, pp. 235-252.

Cordesman, A. (2007). Iraqi Federalism, Separatism, "Hard" Partitioning and US Policy. Center for Strategic and International Studies, (online), pp. 4-7. Available at: http://www.defence.gov.au/library/IPortal/IPortalı.nsf/ LookupByIdentifier/DLSR-78R2JD/\$File/10242007_iraqhardpartition.pdf?OpenElement (Accessed 6 January. 2021).

Cornell, S. (2002). Autonomy as a source of conflict: Caucasian conflicts in theoretical perspective. World Politics, Vol, 54. No2, pp. 245-276.

Connor, W. (1973). The Politics of Ethnonationalism. Journal of International Affairs, Vol. 27, No. 1. Pp. 1-21.

Danilovich, A. (2013). Iraqi Federalism and the Kurds: Learning to Live Together. London: Routledge.

Danilovich, A. (2017). Federalism, Self-Determination and International Recognition Regime: Iraqi Kurdistan at a Crossroads. The Canadian Political Science Association, (online), pp. 3-5. Available at: https://cpsaacsp.ca/documents/conference/2017/Danilovich.pdf (Accessed 5 January. 2021).

DeRouen, R., \& Heo, U. (Eds.). (2007). Civil Wars of the World: Major Conflicts since World War II. California: ABC-CLIO.

Duchacek, I. (1975). External and Internal Challenges to the Federal Bargain. Publius, Vol, 5, No, 2, pp, 4176.

Elazar, J. (1991). Exploring Federalism. Tuscaloosa: University of Alabama Press.

Fearon, J. (1998). Commitment Problems and the Spread of Ethnic Conflict. In ed. David A. Lake \& Donald Rothchild. The International Spread of Ethnic Conflict. London: Cambridge University Press. Pp. 107-126.

Elliott, s., \& beryl, L. (2012). Natural Gas Development in Kurdistan a Financial Assessment. Belfer Center for Science and International Affairs, (online), p. 30. Available at:

https://www.belfercenter.org/sites/default/files/legacy/files/PAE\%2oKurdistan.pdf (Accessed 5 January. 2021).

Friedrich, C. (1968). Trends of Federalism in Theory and Practice. New York: Praeger.

Filippov, M., Ordeshook, P., \& Shvetsova, O. (2004): Designing Federalism: A Theory of Self-Sustainable Federal Institutions. Cambridge University Press.

Gailan, M. (2017). National Security Concerns and the Kurdistan Region in a New Middle East: from Rebellion to Statehood. Unpublished Master Thesis. The Swedish Defence University.

Ghai, Y. (2000). Autonomy as a Strategy for Diffusing Conflict. In Stern, Paul C. and Daniel Druckman (Editor). International Conflict Resolution After the Cold War. Washington, DC: National Academy Press. pp.483-530.

Gunter, M. (2007). A Defacto Kurdish State in Northern Iraq. Third World Quarterly, Vol: 14. No.2. pp. 295-319.

Gurr, T. (2000). Ethnic Warfare on the Wane. Foreign Affairs, Vol, 79. No, 3. Pp 52-110.

Gobel , C., \& Ong, L. (2012). Social Unrest in China. Europe China Research and Advice Network, (online), p. 35. Available at: https://www.chathamhouse.org/sites/default/files/public/Research/Asia/1o12ecran_gobelong.pdf (Accessed 4 January. 2021).

Hale, H. (2004). Divided We Stand: Institutional Sources of Ethnofederal State Survival and Collapse. World Politics, Vol, 56. No, 1, pp. 165-193.

Haysom, N. (2003). Constitution making and nation building. In Blindenbacher, R. \& Koller, A. (eds.) Federalism in a changing 555 world (Montreal and Kingston): McGill Queen's University Press.

Hechter, M. (200o). Containing Nationalism. Oxford: Oxford University.

Hannum, H. (2004). Territorial Autonomy: Permanent Solution or Step towards Secession?. In. Wimmner, A,. Goldstone, R,. Horowitz, D,. Joras, U. \& Schetter, C. Facing Ethnic Conflicts: Towards a New Realism. Oxford: Rowman and Littlefield Publishers, pp. 274-283.

Horowitz, D. (1985). Ethnic Groups in Conflict. New York: University of California Press.

Hueglin, T., \& Fenna, A. (2005). Comparative Federalism: A Systematic Inquiry ist Edition. Toronto: University of Toronto Press.

Ishiyama, J. (2009). Do Ethnic Parties Promote Minority Ethnic Conflict? Nationalism and Ethnic Politics, Vol, 15, No. 1, pp. 56-83.

Kalin, W. (200o). Decentralized Governance in Fragmented Societies: Solution or Cause of New Evils?. In ed Wimmer, A, Goldston, R, Horowitz, D, Joras, U \& Schetter, C. Facing Ethnic Conflicts. Oxford: Littlefield Publishers, pp. 301-310. 
Keil, S., \& Anderson, P. (2018). Decentralization as a Tool of Conflict Resolution. In E. Hepburn and K. Detterbeck (eds.) Handbook of Territorial Politics. Cheltenham: Edward Elgar.

Keil, S. (2012). Federalism as a tool of conflict resolution: the case of Bosnia and Herzegovina. Le Europe en Formation, Vol, 54 No, 363, pp. 205-218

Kincaid, J. (2017). The Eclipse of Dual Federalism by one way Cooperative Federalism. Arizona State Law Journal, Vol, 49, No. 3. pp. 1061-1088.

Kreisberg, L. (1993). Intractable conflict. Peace Review, (online), Vol, 5, No, 4, pp. 417-421.

Kttafah, A., \& Hassan, H. (2017). Challenges Facing the Implementation of Federalism in Iraq: A Case Study of the Contradictions and Inconsistencies in the Sharing of Power between the Central Government and the Regional in Iraq Constitution of 2005. The Social Sciences ISSN, Vol 12. No 12. Pp. 1842-1847.

Lijphart, A. (1977). Democracy in plural societies: a comparative exploration. New Haven: Yale University Press.

Lijphart, A. (2001). The Pros and Cons-but Mainly Pros-of Consensus Democracy. Acta Politica, Vol, 36, No. 2, pp, 129-139.

Levy, J. (2007). Federalism, liberalism, and the separation of loyalties. American Political Science Review, Vol, 101. No, 3, pp. 459-477.

Lorwin, V. (1968). Belgium: religion, class, and language in national politics. In, ed. Robert, D. Political oppositions in western democracies. New Haven: Yale University Press. Pp. 147-87.

Lockhart, P. (2014). Geopolitics, Borders, and Federalism: Challenges for Post-War Iraq. Unpublished Master Thesis. Western Kentucky University.

Mason, D. (200o). Race And Ethnicity In Modern Britain. Oxford: Oxford University Press.

McGarry, J., \& O'Leary, B. (2009). Must Pluri-national Federations Fail?. Journal Ethnopolitics, Vol, 8. No, 1, PP. 525.

McGarry, J. \& O'Leary, B. (2007). Iraq's Constitution of 2005: Liberal consociation as political prescription. International Journal of Constitutional Law, Vol, 5, no, 4, pp. 670-698.

Mistaffa, J. (2018). The Kurds in Iraq: Problem and Solution Attempts. Journal of Political and Security Studies, Vol, 1, Issue I, pp. 127-156.

Mohammed, A. (2013). The Politics of Iraqi Kurdistan: Towards Federalism or Secession?. Canberra: University of Canberra.

Nordlinger, E. (1972). Conflict Regulation in Divided Societies. American Behavioral Scientist, Vol, 15. No, 6, pp. 952-982.

Ostrom, V. (1989). Courts and Collectivities. BYU Law Review, Vol, 15, No, 3.pp, 857-872.

O'Leary, C. (2002). The Kurds of Iraq: Recent History, Future Prospects. Middle East Review of International Affairs, Vol.6, No.4. pp. 17-29.

Olzak, S. (1998). Ethnic protest in core and periphery states. Ethnic and Racial Studies, Vol, 21, No. 2, pp. 187-217.

Rex, J. (1996). Ethnic Minorities in the Modern Nation States. New York: Macmillan.

Roeder, Ph. (2007). Where nation-states come from Institutional change in the age of nationalism. Princeton: Princeton University Press.

Rocher, F., Marie-Christine, G. (2010). Re-Federalizing Canada: Refocusing the Debate on Decentralization," in R. Hubbard, G. Paquet, The Case for Decentralized Federalism. Ottawa: University of Ottawa Press. Pp. 236287.

Romano, D. (2004). Letter from Iraq From Dictatorship to Democracy-Uniting Diversity in the Tent of Federalism. Policy Options-Montreal, (online), para. 2-8. Available at: http://policyoptions.irpp.org/magazines/canadascities/letter-from-iraq-from-dictatorship-to-democracy-uniting-diversity-in-the-tent-of-federalism/ (Accessed 19 December. 2021).

Rogg, I., \& Rimscha, H. (2007). The Kurds as parties to and victims of conflicts in Iraq. International Review of the Red Cross, Vol, 89. No, 868, pp. 823-842.

Rothchild, D., \& Hartzell, C. (1999). Security in Deeply Divided Societies: The Role of Territorial Autonomy. Nationalism and Ethnic Politics, Vol.5, No. 3-4. Pp. 254-271.

Riker, H. (1964). Federalism: Origin, Operation, and Significance. Boston: Little Brown and Company.

Sambanis, N., \& Milanovic, B. (2011). Explaining the demand for sovereignty (English). Policy Research working paper, (online), No 5888. Available at: http://documents.worldbank.org/curated/en/43126146832156109o/pdf /WPS5888.pdf (Accessed 19 December. 2021).

Saayman, M. (2013). Federalism, Trust, and the Problem of Sectarianism in Iraq. Unpublished Master Thesis. The University of Ottawa.

Stepan, A. (1999). Federalism and democracy: beyond the US model. Journal of Democracy, (online), Vol, 10. No, 4, pp. 19-34. 
Smith, S. (1998). Collaborative approaches to Pacific Northwest fisheries management: The salmon experience. Willamette Journal of International Law and Dispute Resolution, Vol, 6. No, 2. Pp, 1- 29.

Smith, A.D. (1986), The Ethnic Origin of Nation, New York: Basil Blackwell. Pp.16-21.

Stone, J. (1995). Race, ethnicity, and the Weberian legacy. American Behavioral Scientist, vol, 38, No, 3, pp. 391-401. Snyder, J. (200o). From Voting to Violence: Democratization and Nationalist Conflict. New York: Norton.

Watts, R. (1999). Comparing Federal Systems: A Comparative Study, Kingston: Institute of Intergovernmental Relations, Queen's University, p. 12.

Wheare, K. (1964). Federal Government (4th edition). Oxford: Oxford University Press, p. 9.

Wing, J. (2012). New Public Opinion Poll on Iraqi Kurdistan's Independence. Available at: http:// www.ekurd. net/mismas/ articles/misc2012/ 10/state6535.htm (Accessed 16 December. 2021).

Williams, P., \& Simpson, M. (2008). Rethinking the Political Future: An Alternative to the Ethno-Sectarian Division of Iraq. American University International Law Review, Vol, 24. No, 2. Pp. 191-247.

Wolff, S. (2010). Approaches to conflict resolution in divided societies: The many uses of territorial selfgovernance. Exeter Centre for Ethno-Political Studies, No. 5 pp. 5-6. 